\title{
Polymorphism in drug resistance genes dihydrofolate reductase and dihydropteroate synthase in Plasmodium falciparum in some states of India
}

Divya Sharma ${ }^{1}$, Manila Lather ${ }^{1}$, Prashant K. Mallick', Tridibes Adak', Amita S. Dang ${ }^{2}$, Neena Valecha ${ }^{1}$ and Om P. Singh ${ }^{1 *}(\mathbb{D}$

\begin{abstract}
Background: Sulfadoxine-pyrimethamine (SP) combination drug is currently being used in India for the treatment of Plasmodium falciparum as partner drug in artemisinin-based combination therapy (ACT). Resistance to sulfadoxine and pyrimethamine in $P$. falciparum is linked with mutations in dihydropteroate synthase (pfdhps) and dihydrofolate reductase (pfdhfr) genes respectively. This study was undertaken to estimate the prevalence of such mutations in pfdhfr and pfdhps genes in four states of India.

Methods: Plasmodium falciparum isolates were collected from two states of India with high malaria incidence i.e., Jharkhand and Odisha and two states with low malaria incidence i.e., Andhra Pradesh and Uttar Pradesh between years 2006 to 2012. Part of sulfadoxine-pyrimethamine (SP) drug resistance genes, pfdhfr and pfdhps were PCR-amplified, sequenced and analyzed.

Results: A total of 217 confirmed P. falciparum isolates were sequenced for both Pfdhfr and pfdhps gene. Two pfdhfr mutations $59 \mathrm{R}$ and $108 \mathrm{~N}$ were most common mutations prevalent in all localities in $77 \%$ of isolates. Additionally, $1164 \mathrm{~L}$ was found in Odisha and Jharkhand only (4/70 and 8/84, respectively). Another mutation 511 was found in Odisha only (3/70). The pfdhps mutations 436A, 437G, 540E and 581G were found in Jharkhand and Odisha only in 13, 26, 14 and $13 \%$ isolates respectively, and was absent in Uttar Pradesh and Andhra Pradesh. Combined together for pfdhps and pfdhfr locus, triple, quadruple, quintuple and sextuple mutations were present in Jharkhand and Odisha while absent in Uttar Pradesh and Andhra Pradesh.

Conclusion: While only double mutants of pfdhfr was present in low transmission area (Uttar Pradesh and Andhra Pradesh) with total absence of pfdhps mutants, up to sextuple mutations were present in high transmission areas (Odisha and Jharkhand) for both the genes combined. Presence of multiple mutations in pfdhfr and pfdhps genes linked to SP resistance in high transmission area may lead to fixation of multiple mutations in presence of high drug pressure and high recombination rate.
\end{abstract}

Keywords: Plasmodium falciparum, Sulfadoxine-pyrimethamine, pfdhfr, pfdhps, India

\footnotetext{
*Correspondence: singh@mrcindia.org

'National Institute of Malaria Research, Sector 8, Dwarka Delhi-110077, India

Full list of author information is available at the end of the article
} 


\section{Background}

Malaria is one of the major health problems in tropical and subtropical countries. One of the greatest challenges to malaria treatment is the development and spread of resistance in parasites especially in Plasmodium falciparum which threaten the usable lifespan of even artemisininbased combination therapies, affecting both the artemisinin component and the partner medicine [1]. India has evidenced resistant parasite especially $P$. falciparum against all available conventional antimalarials like chloroquine (CQ) and sulfadoxine-pyrimethamine (SP) [2]. A decade long use of artemisinin-based combination therapy (ACT) had been proved a hallmark anti-malarial therapy for all the malaria endemic countries [3]. The reports of chloroquine resistance in $P$. falciparum in early 1980 s lead to introduction of $\mathrm{SP}$ as a second line antimalarial drug in CQ-resistant areas of India [4]. Sulfadoxine and pyrimethamine acts as a synergistic combination and was used as long acting partner antimalarial drug in ACT in South Asia, Middle East and South America [3]. Since 2005, Indian antimalarial drug policy has introduced artesunate with SP as ACT in place of SP in high malaria endemic areas, and later in 2010, this treatment became the recommended first line treatment throughout India [5, 6]. Further, since 2013, prevalence of resistant genotype of falciparum against this partner drug SP, led to introduction of artemether-lumefantrine as antimalarial therapy for northeastern part of India $[7,8]$.

The synergistic combination of the sulfadoxine and pyrimethamine inhibits dihydropteroate synthase (dhps) and dihydrofolate reductase $(d h f r)$ enzymes respectively in the folate-pathway of parasite [9]. The development of resistance against SP emerges with a single point mutation in the parasite $d h f r$ and dhps gene, which further augments with stepwise addition of mutations [10-12]. Resistance to pyrimethamine is primarily conferred by a point mutation at codon 108 and augmented by mutations at codon 16, 51, 59 and 164 of Plasmodium falciparum dhfr (pfdhfr) gene [10,12, 13]. Similarly, point mutation at codon 436 or 437 in Plasmodium falciparum dhps (pfdhps) gene may initiate the resistance and followed by mutations at codon 540, 581 and 613, which are considered for augmentation of sulfadoxine resistance $[11,13,14]$.

A single mutation in pfdhfr or pfdhps gene is not enough to cause treatment failure and multiple mutation combinations in these two genes were associated with failure of SP as anti-malarial therapy $[15,16]$. Various parts of India reported single, double, triple and quadruple mutant pfdhfr gene [17-22]. However, double mutation at codon 59 and 108 in pfdhfr gene was predominant throughout India [17-22]. Triple mutant pfdhfr gene indicating high level of antifolate resistance was observed in India from northeast states, Car Nicobar island and Odisha [7, 15, 20, 22, 23]. Highly resistant quadruple mutant allele was observed in high and low frequencies from Car Nicobar island and northeastern parts of India respectively $[19,20,22,24,25]$. Wild-type allele in pfdhps gene was predominant in all geographic regions of India except Andaman and Nicobar island, where lower frequency of mutations in pfdhps gene was observed in comparison to $p f d h f r$ gene, which supports that mutations first emerged in pfdhfr and then occurs in pfdhps gene [23]. Single mutation at codon 437 was observed in low frequency from Assam, Odisha, Madhya Pradesh and Uttar Pradesh [21, 23, 26]. Further, double and triple mutation including mutation at codon 437 was also observed in low frequencies from Madhya Pradesh, northeast and Odisha [20,26, 27]. However, recent studies from northeastern part of India showed increased number of key mutation at codon 437 included in triple and quadruple mutations in pfdhps gene [7, 20,22].

Development of resistance against ACT is currently a major threat and $P$. falciparum bearing resistance against its partner drug (here, SP) may lead to ACT failure [3]. The reports of widespread resistance against SP generate concern about long-term effectiveness of ACT in India [5, 20]. A recent study reported significant reduction in efficacy of SP treatment from northeastern areas of India, which is considered as a gateway for invasion of drug resistant parasite from Southeast Asia to India [7, 20, 22]. Thus, routine molecular surveillance of SP resistance markers is essential in malaria endemic regions, which will help in formulating an effective malaria treatment strategy. Here, we attempted to determine the changes in the frequencies of $d h f r$ and dhps mutations in P. falciparum isolates from four states of India (Jharkhand, Odisha, Andhra Pradesh and Uttar Pradesh) to assess the level of SP resistance.

\section{Methods}

\section{Study population and blood sample collection}

Finger prick blood-spots $(n=217)$ were collected on Whatman $3 \mathrm{MM}$ filter paper from all microscopicallyconfirmed P. falciparum positive patients. This study has been approved by the Institutional Ethics Committee (IEC), and the Scientific Advisory Committee (SAC) of National Institute of Malaria Research. All isolates were collected between years 2006-2012. The study included patients with symptoms of uncomplicated malaria, visiting Primary Health Centre (PHC) situated in the six districts of the four different states of India, i.e., Jharkhand, Odisha, Andhra Pradesh and Uttar Pradesh which are described below. Artemesinin-based combination therapy was implemented as the first line of antimalarials drug for treatment of $P$. falciparum in some districts of Andhra Pradesh, Jharkhand and Orissa since 2008 and in Uttar Pradesh since 2010. Samples were collected from following sites: 
1. Jharkhand: Microscopically confirmed P. falciparum samples were collected from villages under PHC Tamar, district Ranchi $\left(23^{\circ} 23^{\prime} \mathrm{N}\right.$ latitude and $85^{\circ} 23^{\prime}$ E longitude) and East Singhbhum PHC (23 $01^{\circ} \mathrm{N}$ latitude and $86^{\circ} 54^{\prime}$ E longitude). The Annual Parasite Incidence (API, i.e., \%o malaria case in a year) of Jharkhand is $\geq 5[28,29]$. Samples $(n=84)$ were collected between year 2006 and 2011 during which proportion of $P$. falciparum malaria has increased from $24 \%(n=48388)$ to $44 \%(n=70302)$ in Jharkhand state [30].

2. Odisha: Samples were collected from villages under Rayagada PHC $\left(19^{\circ} 09^{\prime} \mathrm{N}\right.$ latitude and $83^{\circ} 27^{\prime} \mathrm{E}$ longitude) and Rourkela PHC ( $22^{\circ} 25^{\prime} \mathrm{N}$ latitude and $85^{\circ} 00^{\prime} \mathrm{E}$ longitude) of Odisha state are belonging to hyper endemic areas show a higher level of drug resistance and intense perennial malaria transmission. API of Odisha is $\geq 5[28,29]$. Odisha alone contributed approximately $25 \%$ of the total malaria cases and $45 \%$ of total falciparum malaria cases reported in the country during recent years (2008-2012). All isolates $(n=70)$ collected from this site between years 2008, 2010-2012 during which proportion of $P$. falciparum malaria increased from $87 \%(n=329631)$ to $93 \%$ $(n=244503)$ [30].

3. Andhra Pradesh: Samples were collected from PHC Salur, district Vizianagaram $\left(18^{\circ} 53^{\prime} \mathrm{N}\right.$ latitude and $83^{\circ} 21^{\prime} \mathrm{E}$ longitude) which is located in the northern part of the Godavari district which is dominated by tribal populations. Malaria endemicity is low, with annual transmission and API of Andhra Pradesh is $\geq 2$ [29]. Samples $(n=32)$ were collection from this site during year 2011. During this period, $P$. falciparum was the predominant malaria spices in Andhra Pradesh and accounting for $70 \%(n=24089)$ of total reported malaria infection [30].

4. Uttar Pradesh: Samples were collected from PHC Razapur, district Ghaziabad (28 $40^{\prime} \mathrm{N}$ latitude and $77^{\circ} 28^{\prime}$ E longitude). Ghaziabad is an industrial area, located in between three river named Hindon, Ganga and Yamuna. Malaria endemicity is low with seasonal transmission and $P$. vivax is the predominant malaria species in this region. API of Ghaziabad is $\geq 2$ [29]. Sample $(n=31)$ were collected from this site during years 2011 and 2012; during that time only $3.25 \%$ $(n=1857)$ and $1.56 \%(n=740)$ of total malaria burden was attributed to $P$. falciparum in same years respectively [30].

\section{DNA isolation and molecular diagnosis}

Genomic DNA was extracted from dried filter paper blood spots using QIAmp Blood mini kit (Qiagen, Krefeld, Germany) as per the manufacture's instruction. A PCR diagnosis was performed to confirm the presence of $P$. falciparum infection and rule out any mixed species infection as described earlier [31].

\section{SNP's genotyping in pfdhfr and pfdhps genes $P C R$ amplification of pfdhfr gene}

A 720 base pair fragment of pfdhfr gene was amplified as described earlier [18] and nested PCR was performed to amplify 648-bp fragment covering various single nucleotide polymorphism (SNP) A16V, N51I, C59R, S108N and $1164 \mathrm{~L}$ correlated with pyrimethamine resistance. Primary PCR $(25 \mu \mathrm{L})$ reaction contained $4 \mu \mathrm{l}$ DNA template, $200 \mu \mathrm{M}$ of dNTPs, $1 \mathrm{x}$ PCR buffer, $0.30 \mu \mathrm{M}$ of primers AMP-1 F and AMP-2R, and $2.5 \mathrm{U}$ Taq polymerase (Sigma, India). The cycling parameters used were as follows: an initial denaturation at $94{ }^{\circ} \mathrm{C}$ for $3 \mathrm{~min}$, denaturation at $94{ }^{\circ} \mathrm{C}$ for $30 \mathrm{~s}$, annealing at $45{ }^{\circ} \mathrm{C}$ for $45 \mathrm{~s}$, and extension at $72{ }^{\circ} \mathrm{C}$ for $45 \mathrm{~s}$, for 45 cycles followed by an extension step at $72{ }^{\circ} \mathrm{C}$ for $5 \mathrm{~min}$. Nested PCR was performed using $2.5 \mu \mathrm{l}$ templates from first round PCR product, $0.30 \mu \mathrm{M}$ of primers M1 and M5, $200 \mu \mathrm{M}$ of each dNTP, 1x PCR buffer, and $1 \mathrm{U}$ of Taq polymerase in a $25 \mu \mathrm{l}$ reaction. The PCR was carried at $94{ }^{\circ} \mathrm{C}$ for $3 \mathrm{~min}$, followed by 35 cycles at $94{ }^{\circ} \mathrm{C}$ for $1 \mathrm{~min}, 45^{\circ} \mathrm{C}$ for $1 \mathrm{~min}, 72{ }^{\circ} \mathrm{C}$ for $1 \mathrm{~min}$ and finally $72{ }^{\circ} \mathrm{C}$ for $10 \mathrm{~min}$. The PCR amplicon was visualized in $2 \%$ Agarose gel. The list of primers used for PCRamplification is provided in Table 1.

\section{PCR amplification of pfdhps gene}

A nested PCR assay was performed to amplify 728-bp fragment of the pfdhps gene covering SNP's S436A, A437G, K540E, A581G and A613S known to be associated with sulfadoxine resistance as described earlier [18]. Primary PCR reaction of $25 \mu \mathrm{L}$ was prepared consisting $4 \mu \mathrm{l}$ DNA template, $200 \mu \mathrm{M}$ of each dNTP, 1x PCR buffer, $0.30 \mu \mathrm{M}$ of primers $\mathrm{M} 3717 \mathrm{~F}$ and $186 \mathrm{R}$ and $2.5 \mathrm{U}$ Taq polymerase (Sigma, India). The cycling parameters used were as follows: an initial denaturation at $94{ }^{\circ} \mathrm{C}$ for $5 \mathrm{~min}$, denaturation at $94{ }^{\circ} \mathrm{C}$ for $30 \mathrm{~s}$, annealing at $55^{\circ} \mathrm{C}$ for $45 \mathrm{~s}$, and extension at $72{ }^{\circ} \mathrm{C}$ for $90 \mathrm{~s}$, for 45 cycles followed by an extension step at $72{ }^{\circ} \mathrm{C}$ for $10 \mathrm{~min}$. Nested PCR

\begin{tabular}{|c|c|c|c|}
\hline $\begin{array}{l}\text { Name of } \\
\text { primers }\end{array}$ & Sequence $\left(5^{\prime}-3^{\prime}\right)$ & Expected size & References \\
\hline AMP-1 F & ТTТТАТTTСТССТTITA & $720 \mathrm{bp}$ & [18] \\
\hline AMP-2R & CATITATTATTCGTITCT & & \\
\hline M1 & TITATGATGGAACAAGTCTGC & $648 \mathrm{bp}$ & {$[38]$} \\
\hline M5 & AGTATATACATCGCTAACAGA & & \\
\hline M3717F & CCATTCCTCATGTGTATACAACAC & $1287 \mathrm{bp}$ & {$[18]$} \\
\hline $186 \mathrm{R}$ & GTTTAATCACATGTTTGCACTTC & & \\
\hline Rc & GGTATTITGTTGAACCTAAACG & $728 \mathrm{bp}$ & [38] \\
\hline $\mathrm{Rd}$ & ATCCAATTGTGTGATTTGTCCAC & & \\
\hline
\end{tabular}


was performed using $2.5 \mu \mathrm{l}$ templates from first round PCR product, $0.30 \mu \mathrm{M}$ forward primer (Rc) and $0.50 \mu \mathrm{M}$ reverse primer (Rd), $200 \mu \mathrm{M}$ of each dNTP, $1 \mathrm{x}$ PCR buffer, and $1 \mathrm{U}$ of Taq in a $25 \mu$ reaction. The PCR was carried at $94{ }^{\circ} \mathrm{C}$ for $4 \mathrm{~min}$, followed by 30 cycles at $94{ }^{\circ} \mathrm{C}$ for $30 \mathrm{~s}, 50^{\circ} \mathrm{C}$ for $40 \mathrm{~s}, 72^{\circ} \mathrm{C}$ for $1 \mathrm{~min}$ and finally $72{ }^{\circ} \mathrm{C}$ for $10 \mathrm{~min}$. The PCR amplicon was visualized in $2 \%$ Agarose gel. The list of primers used for PCRamplification is provided in Table 1.

\section{DNA sequencing and analysis}

All successful nested PCR amplicons were purified using MinElute PCR Purification Kit (Qiagen, Krefeld, Germany) and subjected to DNA sequencing using Big-Dye Terminator Kit version 3.1 (Applied Biosystems, Foster, USA). Sequencing was performed on both strand of DNA to confirm SNP's. The chromatogram was manually edited in Finch TV and mixed bases were carefully scored. Sequences obtained were aligned in software MEGA version 5 [32] using ClustalW implemented in the program with the wild type sequence obtained from GenBank with Accession number J03028.1 and PFU07706 for pfdhfr and pfdhps respectively. DNA sequences obtained were submitted to GenBank (accession numbers KP30040 - KP300256 for pfdhfr and KP300257 - KP300473 for pfdhps gene). The genetic diversity parameters such as haplotype diversity and two measures of nucleotide diversity; $\theta_{w}$ and $\pi$ were estimated in software DnaSP version 5.10.01. The estimation of $\theta_{w}$ and $\pi$ is based on the number of segregating sites and mean number of pairwise nucleotide differences respectively. To test the neutrality in molecular evolution of $p f d h f r$ and pfdhps gene, Tajima's D was calculated based on the normalized discrepancy between $\theta_{\mathrm{w}}$ and $\pi$. Other measures of neutrality such as Fu and Li's D* and Fu and Li's F* were also evaluated.

\section{Sulfadoxine-Pyrimethamine resistance genotypes}

Mutations at both genes were concatenated to form combined mutant genotypes, which in turn provide information about various levels of clinical resistance to SP treatment. In an earlier study [18], the combined mutant genotypes were categorized for following types of clinical resistance; category "S/RI" with single or double mutation in combined genotype infers early emergence of SP resistance; category "RI" with triple mutation in combined genotype suggests low level of SP-resistance; category "RI/RII" with triple mutation in pfdhfr gene suggests initiation of high level SP-resistance; category "RII/RIII" with quintuple mutations in combined genotype suggests higher level of SP-resistance; category "RIII" with sextuple mutations in combined genotype suggests total failure of SP treatment.

\section{Results}

\section{Mutation analysis of pfdhfr and pfdhps genes}

All 217 isolates were successfully sequenced for $p f d h f r$ and pfdhps genes covering codon positions 16, 51, 59,108 and 164 of pfdhfr gene and codons 436, 437,540,581 and 613 of $p f d h p s$ gene. The distribution of amino acid substitution at various codon positions for $p f d h f r$ and $p f d h p s$ genes are shown in Tables 2 and 3 respectively In total, sequencing results showed pure alleles at all the codons in $n=38$ $(17.51 \%)$ isolates. No mutant alleles were detected at codon 16 in pfdhfr gene and at codon 613 in pfdhps gene. In pfdhfr gene, majority of isolates were observed with pure mutant alleles 59R $(n=117,54 \%)$ and $108 \mathbf{N}(n=139$, $64 \%)$ and mixed mutant allele $59 \mathbf{R}^{*}$ was observed in 23.04 \% $(n=50)$ and $108 \mathbf{N}^{*}$ in $18.43 \%(n=40)$ isolates. However, pure mutant alleles 51I $(n=2,0.92 \%)$ and $164 \mathbf{L}$ $(n=7,3.22 \%)$ were less prominent at codons 51 and 164 respectively. Mixed mutant alleles were observed in $0.46 \%$ $(n=1)$ and $2.30 \%(n=5)$ at codon 51 and 164 respectively.

Table 2 Regional distribution of pfdhfr mutations

\begin{tabular}{|c|c|c|c|c|c|c|c|c|c|c|c|c|c|}
\hline \multirow{3}{*}{ State } & \multirow{3}{*}{$\mathrm{N}$} & \multicolumn{12}{|c|}{ pfdhfr genotypes } \\
\hline & & \multicolumn{3}{|l|}{$\overline{N 511}$} & \multicolumn{3}{|l|}{ C59R } & \multicolumn{3}{|l|}{$\mathrm{S} 108 \mathrm{~N}$} & \multicolumn{3}{|l|}{ I164L } \\
\hline & & $\mathrm{N}$ & 1 & $N+1$ & C & $\mathrm{R}$ & $C+R$ & $S$ & $\mathrm{~N}$ & $\mathrm{~S}+\mathrm{N}$ & I & $\mathrm{L}$ & $I+L$ \\
\hline \multicolumn{14}{|c|}{ High transmission areas } \\
\hline Jharkhand & 84 & 84 & - & - & 8 & 46 & 30 & 3 & 55 & 26 & 76 & 4 & 4 \\
\hline Odisha & 70 & 67 & 2 & 1 & 22 & 40 & 8 & 21 & 43 & 6 & 66 & 1 & 3 \\
\hline Total & 154 & $\begin{array}{l}151 \\
(98.05 \%)\end{array}$ & $\begin{array}{l}2 \\
(1.3 \%)\end{array}$ & $\begin{array}{l}1 \\
(0.65 \%)\end{array}$ & $\begin{array}{l}30 \\
(19.5 \%)\end{array}$ & $\begin{array}{l}86 \\
(55.8 \%)\end{array}$ & $\begin{array}{l}38 \\
(24.7 \%)\end{array}$ & $\begin{array}{l}24 \\
(15.6 \%)\end{array}$ & $\begin{array}{l}98 \\
(63.6 \%)\end{array}$ & $\begin{array}{l}32 \\
(20.8 \%)\end{array}$ & $\begin{array}{l}142 \\
(92.2 \%)\end{array}$ & $\begin{array}{l}5 \\
(3.2 \%)\end{array}$ & $\begin{array}{l}7 \\
(4.5 \%)\end{array}$ \\
\hline \multicolumn{14}{|c|}{ Low transmission areas } \\
\hline $\begin{array}{l}\text { Andhra } \\
\text { Pradesh }\end{array}$ & 32 & 32 & - & - & 17 & 8 & 7 & 14 & 10 & 8 & 32 & - & - \\
\hline $\begin{array}{l}\text { Uttar } \\
\text { Pradesh }\end{array}$ & 31 & 31 & - & - & 4 & 23 & 4 & - & 31 & - & 31 & - & - \\
\hline Total & 63 & $63(100 \%)$ & - & - & $\begin{array}{l}21 \\
(33.3 \%)\end{array}$ & $\begin{array}{l}31 \\
(49.2 \%)\end{array}$ & $\begin{array}{l}11 \\
(17.5 \%)\end{array}$ & $\begin{array}{l}14 \\
22.2 \%)\end{array}$ & $\begin{array}{l}41 \\
(65.08 \%)\end{array}$ & $\begin{array}{l}8 \\
(12.7 \%)\end{array}$ & $\begin{array}{l}63 \\
(100 \%)\end{array}$ & - & - \\
\hline
\end{tabular}


Table 3 Regional distribution of pfdhps mutations

\begin{tabular}{|c|c|c|c|c|c|c|c|c|c|c|c|c|c|}
\hline \multirow[t]{3}{*}{ State } & \multirow[t]{3}{*}{$\mathrm{N}$} & \multicolumn{12}{|c|}{ pfdhps genotypes } \\
\hline & & \multicolumn{3}{|l|}{ S436A } & \multicolumn{3}{|l|}{ A437G } & \multicolumn{3}{|l|}{$\mathrm{K} 540 \mathrm{E}$} & \multicolumn{3}{|l|}{ A581G } \\
\hline & & S & A & $S+A$ & A & G & $A+G$ & K & E & $K+E$ & A & G & $A+G$ \\
\hline \multicolumn{14}{|c|}{ High transmission areas } \\
\hline Jharkhand & 84 & 76 & 6 & 2 & 55 & 25 & 4 & 76 & 6 & 2 & 64 & 17 & 3 \\
\hline Odisha & 70 & 58 & 10 & 2 & 58 & 11 & 1 & 57 & 10 & 3 & 70 & - & - \\
\hline Total & 154 & $\begin{array}{l}134 \\
(87.0 \%)\end{array}$ & $\begin{array}{l}16 \\
(10.4 \%)\end{array}$ & $\begin{array}{l}4 \\
(2.6 \%)\end{array}$ & $\begin{array}{l}113 \\
(73.4 \%)\end{array}$ & $\begin{array}{l}36 \\
(23.4 \%)\end{array}$ & $\begin{array}{l}5 \\
(3.2 \%)\end{array}$ & $\begin{array}{l}133 \\
(86.4 \%)\end{array}$ & $\begin{array}{l}16 \\
(10.4 \%)\end{array}$ & $\begin{array}{l}5 \\
(3.2 \%)\end{array}$ & $\begin{array}{l}134 \\
(87.0 \%)\end{array}$ & $\begin{array}{l}17 \\
(11.0 \%)\end{array}$ & $\begin{array}{l}3 \\
(1.9 \%)\end{array}$ \\
\hline \multicolumn{14}{|c|}{ Low transmission areas } \\
\hline $\begin{array}{l}\text { Andhra } \\
\text { Pradesh }\end{array}$ & 32 & 32 & - & - & 32 & - & - & 32 & - & - & 32 & - & - \\
\hline $\begin{array}{l}\text { Uttar } \\
\text { Pradesh }\end{array}$ & 31 & 31 & - & - & 31 & - & - & 31 & - & - & 31 & - & - \\
\hline Total & 63 & $\begin{array}{l}63 \\
(100 \%)\end{array}$ & - & - & $\begin{array}{l}63 \\
(100 \%)\end{array}$ & - & - & $\begin{array}{l}63 \\
(100 \%)\end{array}$ & - & - & $\begin{array}{l}63 \\
(100 \%)\end{array}$ & - & - \\
\hline
\end{tabular}

Year-wise breakup of $p f d h f r$ mutations in different areas has been provided in supplementary Additional file 1: Tables $\mathrm{S} 1$. The haplotype diversity $(\mathrm{Hd})=0.611$ was estimated in pfdhfr gene with variance of haplotype diversity: 0.00081 and standard deviation of haplotype diversity: 0.028. The nucleotide diversity per site estimated was $\mathrm{Pi}=0.00183$, with sampling variance of $\mathrm{Pi}$ : 0.0000005 and standard deviation of Pi: 0.00067 . The average number of nucleotide differences was $\mathrm{k}=0.920$,theta (per sequence) from $S$, Theta-W $=0.668$ and theta (per site) from $S$, Theta-W $=0.00133$.For $d h f r$ gene analysis Tajima's D was 0.65908 (Not significant, $\mathrm{P}>0.10$ ). Fu and Li's D*test and

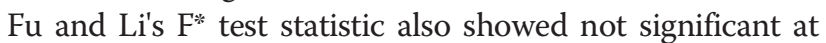
$\mathrm{P}>0.10$ with a value of 0.87589 and 0.95422 respectively. The value of Fu's Fs statistic $=0.001$ and Strobeck's S statistic $=0.685$.

While in $p f d h p s$ gene, wild-type alleles were predominant (79.26 \%, n=172) at all the codons (Table 2). Pure mutant alleles were observed in $7.37(n=16), 16.58(n=36), 7.83$ $(n=17)$ and $7.83 \%(n=17)$ at codons $436,437,540$ and 581 respectively. However, mixed mutant alleles were also prevailed in 1.84, 2.30, 2.30 and $1.38 \%$ at codons 436, 437, 540 and 581 respectively. Year-wise breakup of pfdhps mutations in different sites has been provided in supplementary Additional file 2: Tables S2. The haplotype diversity $\mathrm{Hd}=0.335$ was estimated in pfdhps gene with variance of haplotype diversity $=0.00161$ and standard deviation of haplotype diversity $=0.040$. The nucleotide diversity per site estimated was $\mathrm{Pi}=0.00133$, sampling variance of $\mathrm{Pi}=0.0000004$ and standard deviation of $\mathrm{Pi}=0.00059$. The average number of nucleotide differences was $\mathrm{k}=$ 0.756 , theta (per sequence) from $\mathrm{S}$, Theta- $\mathrm{W}=0.673$ and theta (per site) from $S$, Theta- $\mathrm{W}=0.00118$. For $d$ hps gene analysis Tajima's D was 0.21856 (Not significant, $\mathrm{P}>0.10$ ). The Fu and Li's D* test statistic $=0.87896$ and $\mathrm{Fu}$ and Li's $F^{*}$ test statistic $=0.78220$ were also not statistical significant $(\mathrm{P}>0.10)$. The Fu's Fs statistic $=-2.372$ and Strobeck's S statistic $=0.965$

\section{Mutant genotype status of pfdhfr and pfdhps genes}

In $p f d h f r$ gene, pure wild genotype ANCSI was found in $17.51 \%(n=38)$ isolates. Prevalence of single mutant (ANCNI), double mutant (ANRNI) genotypes were observed in $2.76(n=6)$ and $46.08 \%(n=100)$ isolates while mixed single mutant genotype (ANCN*I) and mixed double mutant genotypes (ANR*N*I) were observed in $2.76(n=6)$ and $23.50 \%(n=51)$ isolates respectively. Pure triple mutant genotypes were two type ANRNL (3.22) and AIRNI (0.92\%) while mixed triple mutant genotypes ANRNL (2.30) and AI*RNI (0.46\%). No quadruple mutant genotypes were found in $p f d h f r$ gene.

In case of pfdhps gene, majority of isolates (79.26\%) were found pure wild genotype SAKAA. SGKAA (1.84\%), $A$ AKAA $(0.46 \%)$ and SAEAA genotype $(0.46 \%)$ are different pure single mutant genotypes, while SA $\boldsymbol{E}^{*} \mathrm{AA}$ $(0.92 \%)$ is mixed single mutant genotype. Prevalence of pure double mutant genotype (SGKGA) and triple mutant genotype (AGEAA) were (7.83) and (6.91\%) respectively, while mixed double mutant $\left(\mathrm{SG}^{*} \mathrm{~K} G^{*} \mathrm{~A}\right)$ and triple mutant ( $\boldsymbol{A} * \boldsymbol{G E A A})$ were $(0.92)$ and $(1.38 \%)$ respectively. Only one isolate showed mixed quadruple mutant genotype i.e. $\boldsymbol{A}$ * $\boldsymbol{G E G A}$.

\section{Two-locus mutation status of pfdhfr and pfdhps genes}

A total of 13 different $p f d h f r$-pfdhps two locus genotypes were observed among 217 isolates which are presented in Table 4. Wild-type two locus genotypes were observed in $17.51 \%(n=38)$ isolates. Mutant two locus genotypes were observed in $82.48 \%(n=179)$ isolates. Out of that, $62.6 \%(n=136)$ isolates showed mutant pfdhfr in the two-locus combination. The majority of isolates (115 of 136) had double mutant pfdhfr (GEN3) while single and 
Table 4 Spatial distribution of pfdhfr and pfdhps allele combinations

\begin{tabular}{|c|c|c|c|c|c|c|c|}
\hline Genotypes & $\begin{array}{l}\text { pfdhfr-pfdhps allele } \\
\text { combination }\end{array}$ & $\begin{array}{l}\text { Resistance } \\
\text { level }^{b}\end{array}$ & $\begin{array}{l}\text { Jharkhand } \\
(\mathrm{n}=84)\end{array}$ & $\begin{array}{l}\text { Odisha } \\
(\mathrm{n}=70)\end{array}$ & $\begin{array}{l}\text { Andhra Pradesh } \\
(\mathrm{n}=32)\end{array}$ & $\begin{array}{l}\text { Uttar Pradesh } \\
(\mathrm{n}=31)\end{array}$ & $\begin{array}{l}\text { Total } \\
(\mathrm{n}=217)\end{array}$ \\
\hline \multicolumn{8}{|l|}{$\begin{array}{l}\text { Wild } \\
\text { genotype }\end{array}$} \\
\hline GEN 1 & ANCSI-SAKAA & $\mathrm{S}$ & $3(3.57)$ & $21(30.00)$ & $14(43.75)$ & & $38(17.51)$ \\
\hline \multicolumn{8}{|l|}{$\begin{array}{l}\text { Mutant } \\
\text { genotypes }\end{array}$} \\
\hline GEN 2 & ANCN ${ }^{a}$ I-SAKAA & $S / R I$ & $4(4.76)$ & $1(1.43)$ & $3(9.38)$ & $4(12.90)$ & $12(5.53)$ \\
\hline GEN 3 & ANR $R^{\mathrm{a}} N^{\mathrm{a}} \mathrm{I}-\mathrm{SAKAA}$ & $\mathrm{S} / \mathrm{Rl}$ & $45(53.57)$ & $28(41.43)$ & $15(46.88)$ & $27(87.10)$ & 115 (52.99) \\
\hline GEN 4 & ANRNI-SGKAA & $\mathrm{Rl}$ & $1(1.19)$ & $1(1.43)$ & & & $2(0.92)$ \\
\hline GEN 5 & ANR $R^{\mathrm{a}} N I-A \mathrm{AKAA}$ & $\mathrm{Rl}$ & & $1(1.43)$ & & & $1(0.46)$ \\
\hline GEN 6 & $\mathrm{ANR}{ }^{\mathrm{a}} N^{\mathrm{a}} \mathrm{I}-\mathrm{SA} E^{\mathrm{a}} \mathrm{AA}$ & $\mathrm{Rl}$ & & $2(2.86)$ & & & $2(0.92)$ \\
\hline GEN 7 & $\mathrm{~A}^{\mathrm{a}} R N \mathrm{I}-\mathrm{SAKAA}$ & $\mathrm{RI} / \mathrm{R} \|$ & & $3(4.29)$ & & & $3(1.38)$ \\
\hline GEN 8 & ANRNL $L^{\mathrm{a}}$-SAKAA & RII & $4(4.76)$ & $2(2.86)$ & & & $6(2.76)$ \\
\hline GEN 9 & ANR ${ }^{a} N^{a} I-S G^{a} K G^{a} A$ & RII & $18(21.42)$ & & & & 18(8.29) \\
\hline GEN 10 & ANRNL-SG ${ }^{\mathrm{a}} K G^{\mathrm{a}} \mathrm{A}$ & RII & $1(1.19)$ & & & & $1(0.46)$ \\
\hline GEN 11 & ANRNI-A $A^{\mathrm{a}} G E A A$ & $\mathrm{RII/RIII}$ & $4(4.76)$ & $8(11.42)$ & & & $12(5.52)$ \\
\hline GEN 12 & $\operatorname{AN} R^{\mathrm{a}} N^{\mathrm{a}} \mid-A^{\mathrm{a}} G^{\mathrm{a}} E^{\mathrm{a}} G^{\mathrm{a}} \mathrm{A}$ & RIII & $1(1.19)$ & & & & $1(0.46)$ \\
\hline GEN 13 & $\mathrm{AN} R^{\mathrm{a}} N^{\mathrm{a}} L^{\mathrm{a}}-A^{\mathrm{a}} G^{\mathrm{a}} E^{\mathrm{a}} A \mathrm{~A}$ & RIII & $3(3.57)$ & $3(4.29)$ & & & $6(2.76)$ \\
\hline
\end{tabular}

${ }^{a}$ mixed (wild + mutant)

${ }^{b}$ resistance level classified as per Ahmed et al. [18]

triple mutant pfdhfr were found in 12 (GEN2) and 9 (GEN7 and GEN8) isolates respectively. Mutant genotype for both genes in the two locus combination was observed in $19.81 \%(n=43)$ isolates. The two locus combined mutant genotypes were categorized into various levels of clinical resistance as described earlier [18], which was based on number of mutations observed in the combination (Table 4). The category "S/RI" representing emergence of SP resistance was observed as genotype GEN2 and GEN3 in $58.52 \%(n=127)$ isolates. The category "RI" suggested low level of resistance against SP treatment was observed as genotype GEN4-6 in $2.30 \%(n=5)$ isolates. The category "RI/RII" suggested for high level of resistance against SP treatment was observed as genotype GEN7 in $1.38 \%$ $(n=3)$ isolates. The category "RII" with quadruple mutation in two locus combination suggested for higher level of resistance against SP treatment was observed as genotype GEN8-10 in $11.52 \%(n=25)$ isolates. The category "RII/RIII" with quintuple mutation in two-locus combination also suggested for higher level of resistance against SP treatment was observed as genotype GEN11 in $5.53 \%$ $(n=12)$ isolates. The category "RIII" with sextuple mutation in two locus combination suggested for level of resistance that can lead to total failure against SP treatment was observed as genotype GEN12-13 in $3.22 \%(n=7)$ isolates.

Spatial distribution of mutations in pfdhfr and pfdhps genes The wild-type ANCSI was observed at all study sites except Uttar Pradesh. Double mutant ANRNI allele in pfdhfr gene was prevalent in all four states Uttar Pradesh $(87 \%, n=31)$, Jharkhand $(83.33 \%, n=84)$, Odisha $(57.14, n=70)$ and Andhra Pradesh $(46.87 \%, n=32)$. Triple mutants ANRNL and AIRNI allele was observed in $(5.71, n=70)$ and $(4.28 \%, n=70)$ isolates respectively at Odisha. Isolates from Jharkhand also showed ANRNL in $(9.52 \%, n=84)$ isolates. Thus mutation $164 \mathrm{~L}$ associated with higher level of drug resistance was present among isolates from Jharkhand (9.52) and Odisha $(5.71 \%)$, which are high transmission regions but not detected in Uttar Pradesh and Andhra Pradesh isolates. Mutation at codon 51 occurred rarely at Odisha $(n=3)$.

The wild-type SAKAA in pfdhps gene was prevalent at Jharkhand $(65.47 \%, n=55)$ and Odisha $(77.14 \%, n=54)$. No mutant pfdhps gene was observed at Andhra Pradesh and Uttar Pradesh. Single key mutation at position 437 (i.e. SGKAA) occurred rarely at Jharkhand $(n=2)$. While Odisha showed single mutant alleles at different positions which were at codon 436 (i.e. $A$ AKAA, $n=1$ ) at key codon 437 (i.e. SGKAA, $n=1$ ) and at codon 540 (i.e. SAEAA, $n=2$ ). Mutation at codon position 581 was existed only in Jharkhand isolates with prevalence $23.80 \%(n=20)$. Double mutant allele SGKGA $(23.80 \%, n=84)$ was observed only in Jharkhand isolates. Thus, Jharkhand and Odisha isolates showed mutations at all codons but with a varied rate. Triple mutant allele $A G E$ AA was observed in isolates from Odisha $(15.71 \%, n=70)$ and Jharkhand $(8.33 \%, n=84)$. Only one isolates from 
Jharkhand showed highly resistant quadruple mutant i.e. AGEGA. No isolate was found to contain S436F and A613S/T mutations.

Uttar Pradesh and Andhra Pradesh showed the twolocus genotype GEN1 categorized as susceptible "S" and genotype GEN2-3 categorized as "S/RI" only. Whereas, Jharkhand and Odisha showed various genotypes categorized for susceptible (S), emerging resistance (S/RI, RI) and also high resistance (RII, RIII). In Jharkhand isolates, double mutant genotype (GEN3) was most prevalent in $53.57 \%$ isolates, whereas the prevalence of triple mutant $(\mathrm{GEN} 4,8)$ and quadruple mutant (GEN9) genotypes were 5.95 and $21.42 \%$ respectively. Highly resistant quintuple mutant genotype (GEN10-11) and sextuple mutant genotype (GEN12-13) were observed in five and four isolates respectively. In Odisha $30 \%$ isolates showed wild-type genotype (GEN1). Like Jharkhand, Odisha also showed prevalence of double mutant genotype (GEN3) i.e. $41.43 \%$ as compared to other mutant genotype. Prevalence of triple (GEN4-8), quintuple (GEN11) and sextuple mutant genotype (GEN12-13) was 12.85, 11.43 and $4.29 \%$ respectively. Quadruple mutant genotype was absent in Odisha.

\section{Discussion}

Currently, combination of fast and long acting antimalarial drugs is recommended as an ideal approach over the use of single antimalarial drug [3]. Optimizing the choice of long acting partner antimalarial drug in ACT is important challenge to be addressed in successful malaria treatment programme [33]. Presence of resistant parasites against the long acting antimalarial used in ACT can hamper the treatment efficacy and can also lead to emergence of artemisinin resistant parasite [7]. All malaria endemic parts of India experienced mutant parasites conferring resistance to all conventional antimalarial drugs like $\mathrm{CQ}$, SP and thus there was country wide adoption of AS + SP as ACT in year 2010 [5]. However, resistance to SP had been well documented from northeastern part of India, which led to use of AS + lumefantrine as first-line malaria treatment in these parts of country since year 2013[7]. Northeast region of India has already been documented as important route for invasion of parasite bearing resistant genotypes against many antimalarials and proved its potential to be a focus for spread of resistant parasite to other parts of country [20]. Thus, monitoring of mutation status of partner SP is important for better management of antimalarial policy. Here, mutation status of $p f d h f r$ and $p f d h p s$ gene responsible for resistance against SP was evaluated for isolates from four different geographic areas.

The study showed 17.51 wild-type pfdhfr gene and $79.26 \%$ wild-type $p f d h p s$ gene. Higher number of mutant pfdhfr gene was observed in comparison to $p f d h p s$ gene at all the study sites infer development of mutations occurred first in pfdhfr gene and then in pfdhps gene under selective drug (SP) pressure. The prevalence of double mutant (ANRNI) in pfdhfr gene and wild-type pfdhps gene at all the study sites corroborated earlier reports of predominant presence for the same [23]. However, single mutant ANCNI, triple mutants (ANRNL or AIRNI) in pfdhfr gene and single mutants (SGKAA, $A$ AKAA and SAEAA), double mutant SGKGA, triple mutant $A G E$ AA, quadruple mutant $A G E G$ A were also observed. Single or double pfdhfr mutations alone cannot cause SP treatment failure but the double $p f d h f r$ mutations with a single or more mutation in pfdhps gene can cause various level of SP resistance [15]. In addition, triple mutant pfdhfr alone can cause various level of SP resistance. The DHFR-DHPS two locus mutations have importance to monitor as it can infer the clinical susceptibility of SP $[15,18]$. This study observed 13 such two locus genotypes (GEN 1-13) within 217 isolates (Table 4). Out of all isolates, only $17.51 \%$ were wild-type (GEN1). In total, double mutant genotype (GEN3) was observed in $52.99 \%$ isolates and its predominance indicates continuous emergence of SP resistance in all study sites. The study sites include both high malaria transmission area (Odisha and Jharkhand) and low malaria transmission areas (Andhra Pradesh and Uttar Pradesh). Triple mutant genotype (GEN 4-8) that can confer high SP resistance were observed in Odisha and Jharkhand with prevalence of 12.85 and $5.95 \%$ respectively, while quadruple mutant (GEN9) was found only in Jharkhand with $21.42 \%$ prevalence. Isolates from high transmission areas also showed quintuple ( Jharkhand $=5.95 \%$, Odisha $=11.43 \%$ ) and sextuple (Jharkhand $=4.76 \%$, Odisha $=4.29 \%$ ) mutant genotype Quintuple and sextuple mutant genotypes associated with higher level of resistance to SP suggests selective drug pressure due to its use since a long period. Here, high transmission areas showed higher number of mixed mutations (both wild and mutant alleles) in both $p f d h f r$ and pfdhps genes, which were possibly due to multi-clonal infection, as high recombination event is expected here, which in turn adding allelic variation. High genetic diversity at these high transmission areas in both gene under selection and neutral microsatellite markers were reported when compared to low transmission region of India [34, 35]. Higher genetic diversity and more fixation probability in genes responsible for various antimalarial resistance was observed earlier and suggested the role of malaria transmission intensity and drug exposure [36, 37]. The mutations $164 \mathrm{~L}$ in pfdhfr and $437 \mathrm{G}$ and $540 \mathrm{E}$ mutations in pfdhps gene were reported to be responsible for therapeutic failure of SP [20,22], and the same were observed in 9.52 and $34.52 \%$ respectively in Jharkhand. In Odisha $4.28 \%$ isolates showed another mutation 51I in $p f d h f r$ gene which was responsible to accelerate the SP-resistance $[15,16]$. In addition, these mutations are 
also part of two-locus genotypes (GEN 7-13) would be involved in clinical resistance against SP. In pfdhps gene, triple mutant $A G E$ AA was found in $15.71 \%$ of Odisha isolates, while double mutant SGKGA is found only in $23.80 \%$ of Jharkhand isolates. The prevalence of mutants found here in high transmission areas are similar to reported earlier from northeastern region [20, 22], however the prevalence of mutant two locus genotypes were not similar. Mutations like S436F, A613T/S was not observed in this study.

In contrast, the low transmission areas (Uttar Pradesh and Andhra Pradesh) showed single mutation (11.11\%) at codon positions 108 , double mutations $(66.67 \%)$ at codon positions 59 and 108 in pfdhfr gene, while no isolate showed the N51I and I164L mutations associated with SP treatment failure. Thus the triple and quadruple mutations were not observed in pfdhfr gene. In case of pfdhps all isolates were wild-types, which infers $P$. falciparum population in these regions were susceptible to SP treatment and resistance could be in developing state. The low transmission areas showed mutations similar to earlier reports of similar single and double mutations from Uttar Pradesh and Delhi in year 2001, which suggested higher susceptibility for SP was maintained due to higher clonal populations in these regions [18]. In addition, $P$. vivax is prevalent in Uttar Pradesh and chloroquine is still effectively used as antimalarial treatment against $P$. vivax in India, which could provide selection pressure on gene responsible for chloroquine resistance in P. falciparum [34]. Thus no or low selection pressure of antifolate drugs in P. falciparum was predicted in these $P$. vivax prevalent areas as misdiagnosed of mixed infection cases was more exposed to chloroquine in comparison to antifolate drug .

\section{Conclusion}

In conclusion, the present findings suggest that SP can be effective for the treatment of uncomplicated falciparum malaria as a partner drug of ACT in Andhra Pradesh and Uttar Pradesh (low transmission areas). In Jharkhand and Odisha (high transmission area), results suggest that mutation rate will increase continuously due to continued drug pressure and malaria transmission, which in turn will lead to SP treatment failure in near future, as reported in northeastern parts of India. Continuous molecular surveillance of partner drug (SP) in these high transmission areas is required to maintain an effective drug policy.

\section{Additional files}

Additional file 1: Table S1. Spatial and temporal distribution of $P$ falciparum dhfr point mutations among Indian isolates. (DOC $57 \mathrm{~kb}$ )
Additional file 2: Table S2. Spatial and temporal distribution of $P$. falciparum dhps point mutations among Indian isolates. (DOC $54 \mathrm{~kb}$ )

\section{Competing interests}

The authors declare that they have no competing interests.

\section{Authors' contributions}

TA, OPS and ASD conceived and deisgned the study, DS ans ML performed laboratory experiments, DS, OPS and PM analyzed the data and wrote the manuscript, All authors read and approved the final manuscript.

\section{Acknowledgements}

DS and ML were supported by University Grant Commission-Senior Research Fellowship. Thanks are due to DBT-IPLS and to Director, NIMR, for funding.

\section{Author details}

${ }^{1}$ National Institute of Malaria Research, Sector 8, Dwarka Delhi-110077, India. ${ }^{2}$ Centre for Medical Biotechnology, Maharshi Dayanand University, Rohtak 124001, India.

Received: 18 June 2015 Accepted: 9 September 2015

Published online: 17 September 2015

\section{References}

1. World Health Organization. Global malaria control and elimination- Report of a technical review. 2008.

2. Dash AP, Valecha N, Anvikar AR, Kumar A. Malaria in India: challenges and opportunities. J Biosci. 2008;33:583-92.

3. Lin JT, Juliano JJ, Wongsrichanalai C. Drug-resistant malaria: the Era of ACT. Curr Infect Dis Rep. 2010;12:165-73.

4. Anvikar AR, Arora U, Sonal GS, Mishra N, Shahi B, Savargaonkar D, et al. Antimalarial drug policy in India: past, present \& future. Indian J Med Res. 2014;139:205-15.

5. Shah NK, Dhillon GP, Dash AP, Arora U, Meshnick SR, Valecha N. Antimalarial drug resistance of Plasmodium falciparum in India: changes over time and space. Lancet Infect Dis. 2011;11:57-64.

6. National Drug Policy on Malaria, 2010, Directorate of National Vector Borne Disease Control Programme, http://nvbdcp.gov.in/doc/drug-policy-2010.pdf, accessed: 6 June 2015.

7. Mishra N, Kaitholia K, Srivastava B, Shah NK, Narayan JP, Dev V, et al. Declining efficacy of artesunate plus sulphadoxine-pyrimethamine in northeastern India. Malar J. 2014;13:284.

8. National Drug Policy on Malaria 2013, Directorate of National Vector Borne Disease Control Programme, http://nvbdcp.gov.in/Doc/National-Drug-Policy2013.pdf, accessed: 6 June 2015.

9. Chulay JD, Watkins WM, Sixsmith DG. Synergistic antimalarial activity of pyrimethamine and sulfadoxine against Plasmodium falciparum in vitro. Am J Trop Med Hyg. 1998;33:325-30.

10. Peterson DS, Walliker D, Wellems TE. Evidence that a point mutation in dihydrofolate reductase-thymidylate synthase confers resistance to pyrimethamine in falciparum malaria. Proc Natl Acad Sci U S A. 1988;85:9114-8.

11. Triglia T, Menting JG, Wilson C, Cowman AF. Mutations in dihydropteroate synthase are responsible for sulfone and sulfonamide resistance in Plasmodium falciparum. Proc Natl Acad Sci U S A. 1997;94:13944-9.

12. Lozovsky ER, Chookajorn T, Brown KM, Imwong M, Shaw PJ, Kamchonwongpaisan S, et al. Stepwise acquisition of pyrimethamine resistance in the malaria parasite. Proc Natl Acad Sci U S A. 2009;106:12025-30.

13. Plowe CV, Cortese JF, Djimde A, Nwanyanwu OC, Watkins WM, Winstanley PA, et al. Mutation in Plasmodium falciparum dihydrofolate reductase and dihydropteroate synthase and epidemiologic patterns of pyrimethaminesulfadoxine use and resistance. J Infect Dis. 1997;176:1590-6.

14. Gregson A, Plowe CV. Mechanisms of resistance of malaria parasites to antifolates. Pharmacol Rev. 2005;57:117-45.

15. Wang P, Lee CS, Bayoumi R, Djimde A, Doumbo O, Swedberg G, et al. Resistance to antifolate in Plasmodium falciparum monitored by sequence analysis of dihydropteroate synthetase and dihydrofolate reductase alleles in a larger number of field samples of diverse origin. Mol Biochem Parasitol. 1997;89:161-77.

16. Kublin JG, Dzinjalamala FK, Kamwendo DD, Malkin EM, Cortese JF, Martino LM, et al. Molecular markers for failure of sulfadoxine-pyrimethamine and 
chlorproguanil-dapsone treatment of Plasmodium falciparum malaria. J Infect Dis. 2002;185:380-8.

17. Srivastava P, Ratha J, Shah NK, Mishra N, Anvikar AR, Sharma SK, et al. A clinical and molecular study of artesunate + sulphadoxine-pyrimethamine in three districts of central and eastern India. Malar J. 2013;12:247.

18. Ahmed A, Bararia D, Vinayak S, Yameen M, Biswas S, Dev V, et al. Plasmodium falciparum isolates in India exhibit a progressive increase in mutations associated with sulphadoxine-pyrimethamine resistance. Antimicrob Agents Chemother. 2004;48:879-89.

19. Ahmed A, Das MK, Dev V, Saifi MA, Wajihullah, Sharma YD. Quadruple mutations in dihydrofolate reductase of Plasmodium falciparum isolates from Car Nicobar Island, India. Antimicrob Agents Chemother. 2006;50:1546-9.

20. Mohapatra PK, Sarma DK, Prakash A, Bora K, Ahmed MA, Sarma B, et al. Molecular evidence of increased resistance to anti-folate drugs in Plasmodium falciparum in North-East India: a signal for potential failure of artemisinin plus sulphadoxine-pyrimethamine combination therapy. PLoS One. 2014;9, e105562.

21. Pathak A, Mårtensson A, Gawariker S, Mandliya J, Sharma A, Diwan V, et al. Characterization of drug resistance associated genetic polymorphisms among Plasmodium falciparum field isolates in Ujjain, Madhya Pradesh. India Malar J. 2014;13:182.

22. Saha P, Guha SK, Das S, Mullick S, Ganguly S, Biswas A, et al. Comparative efficacies of artemisinin combination therapies in Plasmodium falciparum malaria and polymorphism of pfATPase6, pfcrt, pfdhfr, and pfdhps genes in tea gardens of Jalpaiguri District. India Antimicrob Agents Chemother. 2012;56:2511-7.

23. Sharma YD. Molecular surveillance of drug-resistant malaria in India. Curr Sci. 2012;102:696-703.

24. Das MK, Lumb V, Mittra P, Singh SS, Dash AP, Sharma YD. High chloroquine treatment failure rates and pre- dominance of mutant genotypes associated with chloroquine and antifolate resistance among falciparum malaria patients from the island of Car Nicobar. India J Antimicrob Chemother. 2010;65:1258-61.

25. Ahmed A, Lumb V, Das MK, Dev V, Wajihullah, Sharma YD. Prevalence of mutations associated with higher levels of sulphadoxine-pyrimethamine resistance in Plasmodium falciparum isolates from Car Nicobar Island and Assam, India. Antimicrob Agents Chemother. 2006;50:3934-8.

26. Lumb V, Das MK, Singh N, Dev V, Khan W, Sharma YD. Multiple origins of Plasmodium falciparum dihydropteroate synthetase mutant alleles associated with sulfadoxine resistance in India. Antimicrob Agents Chemother. 2011;55:2813-7.

27. Sutar SKD, Dhangadamajhi G, Kar SK, Ranjit M. Molecular monitoring of antimalarial drug resistance among Plasmodium falciparum field isolates from Odisha. India Acta Tropica. 2013;126:84-7.

28. Kumar A, Valecha N, Jain T, Dash AP. Burden of malaria in India: retrospective and prospective view. Am J Trop Med Hyg. 2007;77:69-78.

29. Directorate of National Vector Borne Disease Control Programme. Annual Report 2012, http://nvbdcp.gov.in/Doc/Annual-report-NVBDCP-2012.pdf (accessed: 7 June 2015).

30. Directorate of National Vector Borne Disease Control Programme, Malaria Situation, http://nvbdcp.gov.in/Doc/malaria-situation-may2010.pdf and http://www.nvbdcp.gov.in/Doc/malaria-situation-May14.pdf (accessed: 6 June 2015).

31. Singh B, Bobogare A, Cox-Singh J, Snounou G, Abdullah MS, Rahman HA. $A$ genus and species-specific nested polymerase chain reaction malaria detection assay for epidemiologic studies. Am J Trop Med Hyg. 1998;60:687-92.

32. Tamura K, Peterson D, Peterson N, Stecher G, Nei M, Kumar S. MEGA5: molecular evolutionary genetics analysis using maximum likelihood, evolutionary distance, and maximum parsimony methods. Mol Bio Evol. 2011;28:2731-9.

33. Noedl H, Socheat $D$, Satimai W. Artemisinin resistant malaria in Asia. N Engl J Med. 2009;361:540-1.

34. Mallick PK, Joshi H, Valecha N, Sharma SK, Eapen A, Bhatt RM, et al. Mutant pfcrt "SVMNT" haplotype and wild type pfmdr1 "N86" are endemic in Plasmodium vivax dominated areas of India under high chloroquine exposure. Malar J. 2012;11:11-6.

35. Mallick PK, Sutton PL, Singh R, Singh OP, Dash AP, Singh AK, et al. Microsatellite analysis of chloroquine resistance associated alleles and neutral loci reveal genetic structure of Indian Plasmodium falciparum. Infect Genet Evol. 2013;19:164-75.
36. Lumb V, Das MK, Singh N, Dev V, Wajihullah, Sharma YD. Characteristics of genetic hitchhiking around dihydrofolate reductase gene associated with pyrimethamine resistance in Plasmodium falciparum isolates from India. Antimicrob Agents Chemother. 2009;53:5173-80.

37. Mallick PK, Singh R, Singh OP, Singh AK, Bhasin VK, Valecha N. Reduced heterozygosity at intragenic and flanking microsatellites of pfcrt gene establishes natural selection based molecular evolution of chloroquineresistant Plasmodium falciparum in India. Infect Genet Evol. 2013;20:407-12.

38. Lau TY, Sylvi M, William T. Mutational analysis of Plasmodium falciparum dihydrofolate reductase and dihydropteroate synthase genes in the interior division of Sabah. Malaysia Malar J. 2013;12:445.

\section{Submit your next manuscript to BioMed Central and take full advantage of:}

- Convenient online submission

- Thorough peer review

- No space constraints or color figure charges

- Immediate publication on acceptance

- Inclusion in PubMed, CAS, Scopus and Google Scholar

- Research which is freely available for redistribution 